\title{
Asosiasi Vegetasi Terhadap Komunitas Burung di Kampus I Universitas Kuningan
}

\author{
Nurdin $^{1)}$, Ai Nurlaila ${ }^{2)}$, Dede Kosasih ${ }^{3)}$, Nina Herlina ${ }^{4)}$ \\ ${ }^{14}$ Program Studi Ilmu Lingkungan. Fakultas Kehutanan Universitas Kuningan \\ ${ }^{2}$ Program Studi Kehutanan. Fakultas Kehutanan Universitas Kuningan \\ email: nurdin@uniku.ac.id \\ email: ai.nurlaila@uniku.ac.id \\ email: dede.kosasih@uniku.ac.id \\ email: nina.herlina@uniku.ac.id
}
APA Citation: Nurdin., Nurlaila, A., Kosasih, D., \&Herlina, N. (2020). Asosiasi Vegetasi Terhadap Komunitas Burung Di Kampus I Universitas Kuningan. Quagga: Jurnal Pendidikan dan Biologi, 12(2), 145-155, doi: 10.25134/quagga.v12i2.2672.

\author{
Received: 04-05-2020
}

Accepted: 04-06-2020

Published: 01-07-2019

\begin{abstract}
Abstrak: Interaksi ekologis antara vegetasi dan burung di Kampus I Universitas Kuningan merupakan sifat naluriah alami yang membentuk suatu asosiasi saling menguntungkan. Pembangunan dikhawatirkan berdampak terhadap penurunan tingkat keanekaragaman jenis burung sebagai bioindikator kualitas lingklungan. Penelitian ini ditujukan untuk mengetahui kekayaan, keanekaragaman, dominansi jenis pohon dan burung, serta menganalisis asosiasi pohon terhadap komunitas burung di Kampus I UNIKU. Hasil analisis data terdapat 42 jenis dan 378 pohon, tingkat kekayaan $(D M g=6,9)$ dan keanekaragaman jenis $\left(H^{\prime}=2,9\right)$ termasuk sedang didominasi oleh Polyalthia longifolia 86 batang. Burung tercatat 19 jenis dan 1485 ekor, tingkat kekayaan $(D M g=2,47)$ dan keanekaragaman jenis $\left(H^{\prime}=1,67\right)$ katagori rendah didominasi oleh Passer montanus 652 ekor. Asosiasi vegetasi pohon dan burung berdasarkan Key Performance Indeks (KPI) pada penilaian terhadap fungsi ekologis pohon menunjukan bahwa persentase jumlah tertinggi dengan katagori sangat baik (SB) adalah fungsi modifikasi sebagai pohon penaung 22 jenis. Sedangkan pada fungsi sebagai kontrol kelembaban udara dan menghadirkan burung dengan katagori baik (BA) terdapat 13 jenis. Katagori buruk (BU) terdapat 2 jenis yaitu pada fungsi sebagai kontrol kelembaban udara dan menghadirkan burung. Kesimpulan penelitian ini bahwa asosiasi vegetasi pohon dan burung berdasarkan KPI pada penilaian terhadap fungsi ekologis pohon untuk memodifikasi suhu sebagai penanung, pengontrol kelembaban udara, dan fungsi menghadirkan burung katagori baik. Semakin tinggi nilai keanekeragaman jenis tumbuhan dan burung di Kampus I UNIKU, maka semakin tinggi pula kekayaan jenisnya.
\end{abstract}

Kata Kunci: asosiasi biotik; keanekeragaman hayati; ekologi; komunitas burung; pohon

\begin{abstract}
The ecological interaction between vegetation and birds at Campus I of Kuningan University is a natural instinctive nature that forms a mutually beneficial association. Development is feared to have an impact on reducing the level of bird species diversity as a bio-indicator of environmental quality. This study aimed to determine the richness, diversity, dominance of tree and bird species, and analyze the association of trees with bird communities in Campus I of UNIKU. The results of data analysis found 42 species and 378 trees, level of wealth $(D M g=6.9)$ and species diversity $\left(H^{\prime}=2.9\right)$, including being dominated by 86 Polyalthia longifolia stems. Birds recorded 19 species and 1485 birds, level of wealth $(D M g=2.47)$ and species diversity $\left(H{ }^{\prime}=1.67\right)$ low category is dominated by Passer montanus 652 tails. The association of tree and bird vegetation based on the Key Performance Index (KPI) in the assessment of the ecological function of the tree shows that the highest percentage of numbers with a very good category $(S B)$ is a modification function as a shade tree of 22 species. While the function as a control of humidity and presents birds with good categories (BA) there are 13 species. There are 2 types of bad categories (BU), namely the function as air humidity control and presenting birds. The conclusion of this study is that the association of tree and bird vegetation is based on KPI in assessing the ecological function of trees to modify temperature as a buffer, controlling humidity, and the function of presenting birds in good categories. The higher the diversity value of plant and bird species in UNIKU Campus I, the higher the species richness.
\end{abstract}

Keywords: biotic associations; biodiversity; ecology; bird community; tree 


\section{PENDAHULUAN}

Global warming dan penipisan lapisan ozon menjadi isu lingkungan global yang salah satu dampaknya adalah punahnya flora dan fauna yang dipicu oleh ekploitasi yang berlebihan (Sutoyo, 2010). Pembangunan infrastruktur di Kampus I UNIKU telah mempersempit persentase luasan ruang terbuka hijau (RTH) dan cenderung mengalami konversi guna lahan menjadi kawasan terbangun (Hendriani, 2016) yang berdampak pada perubahan kualitas lingkungan. Pengelolaan lingkungan yang tidak bijaksana dapat menyebabkan degradasi lingkungan yang berimbas pada penurunan kualitas dan kuantitas habitat burung. Burung sebagai indikator adanya perubahan lingkungan, dapat digunakan sebagai indikator dalam mengambil suatu keputusan tentang rencana strategis dalam rangka konservasi lingkungan yang lebih luas (Paramita et al, 2015). Selain itu burung juga merupakan satwa yang dinilai penting pada ekosistem taman karena turut membantu penyerbukan bunga, penyebaran benih, dan mencegah kerusakan tumbuhan dari serangga (Endah \& Partasasmita, 2015). Bahkan tumbuh-tumbuhan dapat berpengaruh terhadap keanekaragaman jenis burung pada suatu tipe habitat (Nurmaeti et al., 2018). Penemuan jenis burung sangat berkaitan erat dengan kondisi habitatnya. Satwa akan memilih habitat yang memiliki kelimpahan sumberdaya bagi kelangsungan hidupnya, sebaliknya jarang atau tidak ditemukan pada lingkungan yang kurang menguntungkan baginya (Rohiyan, 2014).

Berdasarkan latar belakang tersebut perlu penelitian tentang kekayaan, keanekaragaman, dominansi jenis pohon dan burung, serta menganalisis asosiasi pohon terhadap komunitas burung di Kampus I UNIKU.

\section{METODOLOGI PENELITIAN}

Jenis penelitian adalah penelitian survey. Penelitian dilaksanakan pada bulan Mei 2019 sampai dengan Juli 2019. Tempat penelitian dilaksanakan di Kampus I Universitas Kuningan dengan luas 5 ha. Lokasi penelitian dibagi ke dalam 8 area, yaitu Fakultas Ekonomi (FE) dan Fakultas Hukum (FHum), Fakultas Kegururan \& Ilmu Pendidikan (FKIP), area Mesjid Daarul Mutaalimin (MDM), area Scudent Centre (SC) dan Fakultas Kehutanan (FHut), area Parkir Motor Mahasiswa (PMM), area Rektorat, area Lapangan Upacara (LU), dan area Fakultas
Komputer (FKom). Pembagian areal penelitian didasarkan pada pembatas jalan yang memisahkan antar areal seperti terlihat pada gambar 1.

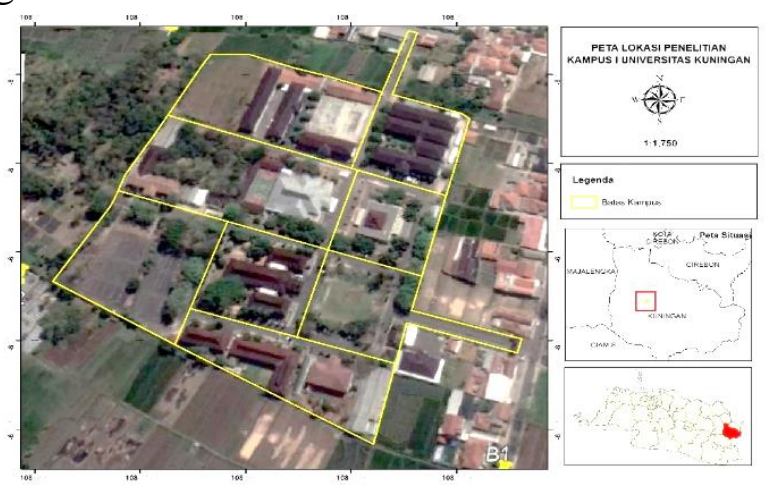

Gambar 1. Peta Lokasi Penelitian

Bahan yang digunakan dalam penelitian ini adalah pohon dan burung di Kampus I UNIKU. Alat-alat yang dipergunakan, yaitu jam tangan untuk mencatat waktu perjumpaan, Binokuler digunakan untuk membantu melihat objek lebih jelas, kamera untuk dokumentasi objek dan kegiatan selama penelitian di lapangan, alat tulis menulis (pensil, spidol dan buku), tally sheet berfungsi untuk mencatat data-data yang diperoleh, global positioning system (GPS) untuk mengetahui titik-titik posisi pengamatan dan komputer beserta kelengkapannya; Microsoft Word, Microsoft Excel dan ArcGIS.

Prosedur pengambilan data burung menggunakan metode Concentration Counts. Menurut Alikodra (1990) bahwa metode concentration counts efektif digunakan untuk mengetahui populasi satwaliar yang mempunyai pola hidup berkelompok. Pengamatan dilakukan pada pagi hari pukul 05.30 WITA dan berakhir pukul 07.30 WIB, atau pada sore hari mulai pukul 16.00 WIB sampai pukul 18.00 WIB. Pengambilan data pohon menggunakan metode sensus inventarisasi vegetasi pada tingkat pertumbuhan pohon yang terdapat di seluruh areal Kampus I UNIKU sesuai dengan pembagian sebelumnya. Pengambilan data dengan menggunakan metode sensus akan mendapatkan data yang lebih akurat.

Analisis data yang dilakukan meliputi:

a. analisis kekayaan jenis, merupakan ukuran jumlah total jenis yang ditemukan pada suatu komunitas melalui Indeks Margalef ( $\left.\mathrm{D}_{\mathrm{Mg}}\right)$ (Ludwig \& Reynolds, 1988). Bahwa semakin tinggi nilai indeks maka jenis tersebut akan memiliki kekayaan jenis 
yang melimpah. Rumus Indeks Margalef adalah sebagai berikut:

$$
D_{M g}=\frac{S-1}{\ln (N)} ;
$$

Keterangan:

$\mathrm{D}_{\mathrm{Mg}}=$ Notasi untuk Indeks Margalef;

$\mathrm{S}=$ Jumlah jenis yang ditemukan (jenis);

$\mathrm{N}$ = Total individu dari seluruh jenis yang dijumpai

b. Indeks keanekaragaman merupakan ukuran matematis bagi keanekaragaman spesies dalam suatu komunitas. Indeks Keanekaragaman jenis yang akan digunakan dalam penelitian ini adalah persamaan Shannon-Wiener (Magurran, 1988), dengan rumus sebagai berikut:

$$
H^{\prime}=-\Sigma\left(\frac{n_{i}}{N}\right) \ln \left(\frac{n_{i}}{N}\right)
$$

Keterangan:

$\mathrm{H}^{\prime}=$ Indeks keanekaragaman ShannonWiener

$\mathrm{n}_{\mathrm{i}}=$ Jumlah individu spesies ke-i

$\mathrm{N}=$ Total individu dari seluruh spesies

Nilai perhitungan index keragaman (H') menunjukkan bahwa :

$\mathrm{H}^{\prime}>3$ : Keragaman spesies tinggi

$1>\mathrm{H}^{\prime}>3$ : $\quad$ Keragaman spesies sedang

$\mathrm{H}^{\prime}<1 \quad$ : Keragaman spesies rendah

c. Indeks dominansi jenis, ditentukan dengan melihat jumlah individu pada setiap jenis yang ditemukan hasil inventarisasi. Jika jumlah individu semakin banyak, maka jenis tersebut akan mendominasi pada areal tersebut.

d. penilaian fungsi ekologis pohon, dilakukan untuk mengetahui nilai secara kuantitatif dan deskriptif keberadaan vegetasi pohon. Hasil penilaian akan mengetahui tingkat kenyamanan bagi pengguna berdasarkan fungsi ekologis pohon sebagai pemodifikasi suhu, pengontrol kelembaban udara, peredam kebisingan, penahan angin, serta habitat bagi kehadiran satwa (burung) (Tabel 1).

Berdasarkan Hidayat (2008), teknik penilaian fungsi ekologis dilakukan berdasarkan komponen fungsi ekologis vegetasi pohon pada tapak. Rumus yang digunakan untuk dapat menentukan kriteria tersebut adalah sebagai berikut :

$\mathrm{KPI}=$ jumlah masing-masing kriteria penilaian Jumlah ideal (total maksimum) masing masing kriteria

KPI: Key Performance Index

Terdapat empat kategori penilaian (sangat baik, baik, kurang baik, dan buruk) yang diberikan pada masing-masing spesies melalui kriteria fungsi yang diberikan, dalam penelitian ini yaitu sebanyak tiga kriteria dari ciri morfologis terbaik pohon yang sesuai dengan fungsinya. Menurut Hidayat (2008), nilai atau skor yang paling sempurna adalah sebesar $100 \%$ apabila masing-masing kriteria fungsi memenuhi penilaian paling sempurna dari akumulasi (Tabel 2). Presentase pembobotan dengan 4 kriteria adalah sebagai berikut :

4 : Sangat baik (bila pemenuhan kriteria $\geq 81 \%$ )

3 : Baik (bila pemenuhan kriteria 61-80\%)

2 : Kurang baik (bila pemenuhan kriteria 4160\%)

1 : Buruk (bila pemenuhan kriteria $\leq 40 \%$ )

Tabel 1. Variabel Fungsi Ekologis dan Kriteria Penilaian

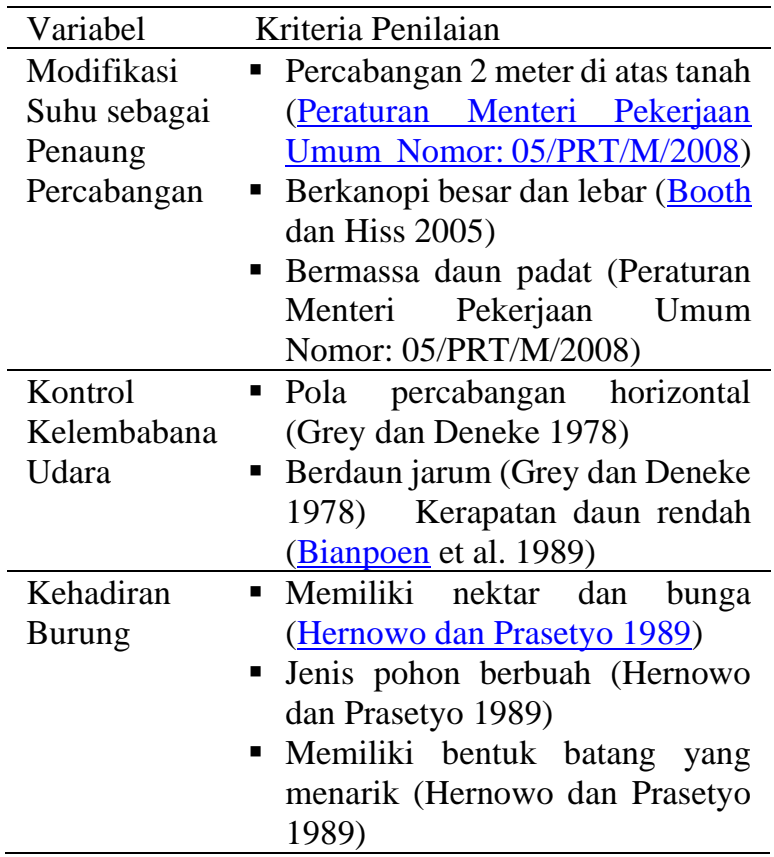


Tabel 2. Format Penilaian Fungsi Ekologis Individu Pohon

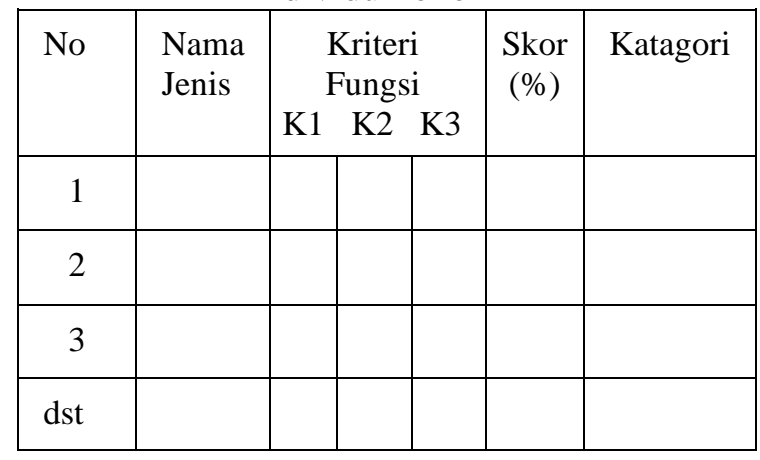

\section{HASIL DAN PEMBAHASAN}

\section{A. Kekayaan dan Keanekaragaman Jenis}

\section{Burung}

Pengumpulan data kekayaan dan keanekaragaman jenis burung yang diperoleh dari hasil survey di 8 areal penelitian Kampus I UNIKU dengan menggunakan metode penghitungan titik konsentrasi (concentration count method) menunjukna hasil yang berbedabeda. Kedelapan areal penelitian tersebut yaitu FE, FHum, FKIP, MDM, SC, FHut, PMM, Rektorat, LU, dan FKom.

Berdasarkan hasil pengamatan lapangan ditemukan 19 jenis burung, 1485 ekor jumlah individu yang tercatat (Tabel 3). Indeks kekayaan jenis $\left(\mathrm{D}_{\mathrm{Mg}}=2,47\right)$ dan indeks keanekaragaman jenis termasuk katagori sedang $\left(H^{\prime}=1,67\right)$. Hasil ini dipengaruhi oleh keanekaragaman jenis vegetasi pohon di areal penelitian yang akan menyediakan berupa bijibijian, serangga, nektar dan buah. (Tabel 3). Suatu areal atau habitat dengan vegetasi yang berbeda, akan cenderung menaikan keanekaragaman jenis burung (Apriliano et al. 2017). Jenis pakan komunitas burung di Kampus I UNIKU terdiri dari burung pemekan biji (granivore), pemakan serangga (insectivore), pemakan buah (frugivore), pemakan nektar (nectarivore) dan pemakan daging (carnivore). Jenis granivore dan insektivore mendominasi dari seluruh komunitas burung di Kampus I UNIKU (Gambar 3). Hal ini sesuai dengan pernyataan Jarulis \{(2005) dalam Hadinoto dkk. (2012) dalam Nurmaeti dkk. (2018)\} bahwa kehadiran jenis burung kemungkinan disebabkan oleh perbedaan jenis tumbuhan, tingkat kenyamanan dan habitat pendukung yang berdekatan, selanjutnya faktor keamanan dari berbagai bentuk gangguan, struktur dan komposisi jenis vegetasi dan luas lokasi dapat mempengaruhi jumlah jenis burung pada suatu kawasan. Jumlah jenis setiap areal penelitian berbeda sesuai dengan karakteristik habitatnya. Komunitas burung mempunyai banyak karakteristik yang potensial untuk dijadikan sebagai indikator ekologis (O'Connell et al. 2000.

\section{Tumbuhan}

Hasil pengamatan pohon di 8 areal penelitian Kampus I UNIKU dengan menggunakan metoded sensus diperoleh 42 jenis. Indeks kekayaan $\left(\mathrm{D}_{\mathrm{Mg}}\right)$ mencapai 6,9 dan indeks kekayaan jenis $\left(\mathrm{H}^{\prime}=2,9\right)$ termasuk pada katagori sedang (Tabel 4). Polyalthia longifolia merupakan pohon yang mendominasi dengan jumlah 86 pohon atau 22,7\% yang berada di sisi kanan dan kiri jalan di dalam areal penelitian. Pohon-pohon yang berbuah dan berbunga sebagai pakan burung jumlahnya relatif sedikit kurang dari 5\%. .Beragamnya jenis vegetasi yang terdapat pada suatu habitat mendukung ketersediaan pakan bagi burung, sehingga dengan beragamnya jenis vegetasi, maka burung akan mendapatkan pilihan yang lebih banyak untuk memilih jenis pakan (Tews et al. 2004). Keanekaragaman habitat berpengaruh terhadap keanekaragaman jenis burung (Crozier dan Niemi 2003; Davidar et al. 2001; Welty, 1982).

\section{Kekayaan dan Keanekaragaman Jenis pada Setiap Areal Penelitian}

Pohon dan komunitas burung pada 8 areal penelitian memiliki jumlah jenis yang berbeda (Gambar 2). Keanekaragaman jenis burung berhubungan dengan ketersediaan sumberdaya yang dibutuhkan oleh burung dan kualitas ekosistem suatu areal. Semakin banyak sumberdaya yang tersedia di suatu areal, maka akan semakin banyak juga jenis-jenis burung yang menempati.

Hasil pengamatan di areal FE-FHUM indeks kekayaan jenis $\left(\mathrm{D}_{\mathrm{Mg}}\right)$ dan indeks keanekaragaman jenis (H') berada pada katagori rendah $\left(\mathrm{H}^{\prime}<1\right)$ (Tabel 4). Pohon hanya satu jenis yaitu Mangifera indica dengan kualitas tajuk pohon rindang, banyak percabangan berukuran besar. Kondisi tersebut mendukung fungsi ekologis dari pohon sehingga kelimpahan burung berada pada katagori sedang.

Di areal FHUT-KSR-SC indeks kekayaan jenis pohon dan burung berbanding lurus dengan nilai indeks kekayaan jenis burung dan pohon 
yang berada pada katagori sedang (Tabel 4.) Banyaknya pohon-pohon yang tingginya lebih dari 6 meter dengan lebar tajuk rata-rata 3 meter menjadikan lingkungan yang cocok untuk kebaradaan berbagai jenis burung. Habitat yang memiliki jenis vegetasi yang beragam akan menyediakan lebih banyak jenis pakan, sehingga pilihan pakan bagi burung akan lebih banyak. Pepohonan memberikan sumber daya bagi kehidupan burung yakni memberikan sumber pakan dan tempat berlindung sebagai hal mendasar untuk bertahan hidup dan berkembang biak.

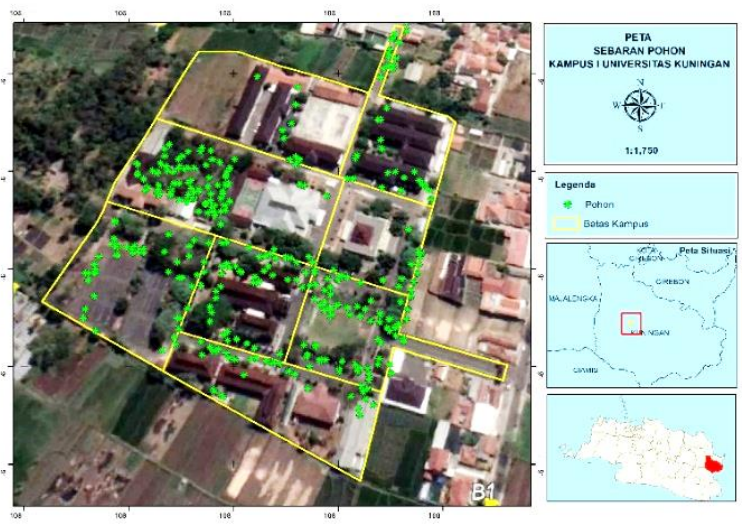

Gambar 2. Sebaran pohon di lokasi penelitian

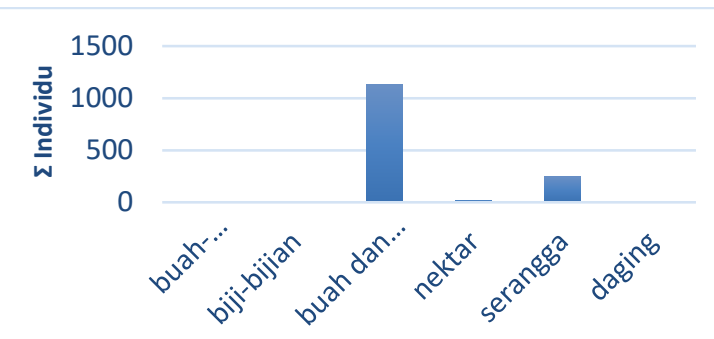

Komunitas Burung Berdasarkan...

Gambar 3. Prosentase komunitas burung berdasarkan pakan

\section{B. Kekayaan dan Fungsi Ekologis Pohon}

Keberadaan ruang terbuka hijau di lingkungan Kampus I Universitas Kuningan sangat penting, karena mempunyai berbagai fungsi dan nilai untuk diaktualisasikan dalam suatu asosiasi antara manusia, tumbuhan dan satwa. Dari berbagai fungsi, nilai dari ruang terbuka hijau dapat diklasifikasikan menjadi empat kategori, yaitu: nilai ekologis dan alam, nilai sosial dan budaya, nilai psikologis, dan nilai estetika atau keindahan (Bradley dan Milward, 1984).

\section{Modifikasi Suhu sebagai Penaung}

Jumlah pohon besar yang berada di Kampus I UNIKU dengan rata-rata diameter 26,6 cm dan tinggi 10,1 m sejumlah 378 individu sehingga suasana lingkungan kampus terasa sejuk dan nyaman berpadu dengan merdunya kicaua suara burung. Karena itu kelembaban udara perlu dikontrol agar penghuni kampus dapat menikmati kenyamanan.

Berdasarkan penilaian karakter fisik yang sesuai dengan karakter fungsi peneduh, maka yang termasuk ke dalam kategori sangat baik (SB) 22 jenis, katagori baik (BA) 15 jenis, dan katagori kurang baik (KB) 5 jenis. Skor rata-rata Key Performance Indeks (KPI) untuk aspek fungsi modifikasi suhu sebagai penaung adalah $77 \%$ termasuk katagori baik (BA). Melihat hasil analisis tersebut, maka Kampus I UNIKU mempunyai kondisi lingkungan yang yang teduh, sejuk, rindang, dan asri dengan ternaungi oleh berbagai jenis pohon-pohonan.

Robinette (1983) mengemukakan bahwa area yang ternaungi menerima sedikit energi radiasi matahari dibandingkan dengan area yang terbuka sehingga area ternaungi memiliki suhu yang lebih rendah. Menurut Booth (1983) suhu udara di dalam bayang-bayang kanopi ini dapat lebih rendah $8 \mathrm{oC}$ daripada ruang terbuka.

\section{Kontrol Kelembaban Udara}

Kelembaban udara merupakan salah satu faktor penting dalam meningkatkan kenyamanan, sehingga perlu adanya kontrol thermal untuk memantau tingkat kenaikan suhu lokal atau global. Suhu dan kelembaban udara yang terkontrol akan mempengaruhi terhadap kehadiran burung di areal Kampus I UNIKU (Tabel 5). Berdasarkan penilaian karakter fisik yang sesuai dengan karakter fungsi kontrol kelembaban udara, maka yang termasuk ke dalam kategori sangat baik (SB) 14 jenis, katagori baik (BA) 12 jenis, katagori kurang baik (KB) 13 jenis, dan katagori buruk (BU) 2 jenis. Skor rata-rata Key Performanc e Indeks (KPI) untuk aspek fungsi modifikasi suhu sebagai penaung adalah $69 \%$ termasuk katagori baik (BA). Melihat hasil analisis tersebut, maka Kampus I UNIKU mempunyai kondisi lingkungan yang yang teduh, sejuk, rindang, dan asri dengan ternaungi oleh berbagai jenis pohon-pohonan sehingga suhu dan kelembaban bisa terjaga.

Kelembaban udara yang ideal dimana manusia dapat beraktivitas dengan nyaman adalah sekitar 40-75\% (Laurie, 1986). 
Berdasarkan Keputusan Menteri Kesehatan No.829/Menkes/SK/VII/1999, Kelembaban udara yang nyaman bagi lingkungan permukiman sehat yaitu sekitar 40-70\%, Sedangkan relative humidity $(\mathrm{RH})$ daerah kenyamanan (comfort zone) bagi badan manusia adalah 45-50\% (Bianpoen et al.,1989).

\section{Kehadiran Satwa (Burung)}

Keragaman pohon di Kampus I UNIKU telah mampu menjadi daya tarik bagi berbagai jenis satwea khususnya burung. Keberadaan pohon-pohon ini juga mampu menjadikan habitat bagi satwa burung untuk berkembang biak dan mencari makan. Hadirnya satwa ini diharapkan menjadi salah satu indikator biologis dan merupakan komitmen untuk mewujudkan UNIKU Green Campus. Tabel 5 menyajikan penilaian berdasarkan kriteria yang telah ditentukan untuk aspek fungsi ekologis di dalam menghadirkan satwa burung.

Berdasarkan penilaian karakter fisik yang sesuai dengan karakter fungsi mengndang kehadiran satwa (burung), maka yang termasuk ke dalam kategori sangat baik (SB) 14 jenis, katagori baik (BA) 13 jenis, katagori kurang baik (KB) 13 jenis, dan katagori buruk (BU) 2 jenis. Skor rata-rata Key Performance Indeks (KPI) pada hasil penilaian aspek fungsi mengndang kehadiran satwa (burung) adalah $63 \%$ termasuk katagori baik (BA). Melihat hasil analisis tersebut, maka Kampus I UNIKU mempunyai kondisi lingkungan yang mampu memberikan perlindungan, mencari makan, dan berkembang biak bagi berbagai jenis burung. Kehadiran burung sangat berperan untuk dapat menciptakan kawasan yang asri dan mampu mengakomodasi habitat satwa tersebut melalui keragaman jenisnya.

\section{SIMPULAN}

Berdasarkan tujuan dan hasil penelitian, maka dapat disimpulkan:

Terdapat 42 jenis dari 378 pohon, termasuk pada tingkat kekayaan dan keanekaragaman jenis sedang yang didominasi oleh Polyalthia longifolia. Sedangkan untuk burung tercatat 19 jenis dari 1485 ekor, termasuk pada tingkat kekayaan dan keanekaragaman jenis sedang didominasi oleh Passer montanus.

Asosiasi vegetasi pohon dan burung berdasarkan Key Performance Indeks (KPI) pada penilaian terhadap fungsi ekologis pohon untuk memodifikasi suhu sebagai penaung, fungsi pengontrol kelembaban udara, dan fungsi menghadirkan burung termasuk pada katagori baik. Semakin tinggi nilai keanekeragaman jenis tumbuhan dan burung di Kampus I UNIKU, maka semakin tinggi pula kekayaan jenisnya dan begitupun sebaliknya.

\section{UCAPAN TERIMA KASIH}

Kami mengucapkan terima kasih kepada Prodi Pendidikan Biologi, Fakultas Keguruan dan Ilmu Pendidikan (FKIP) Universitas Kuningan sebagai penyelenggara seminar nasional, Dekan dan rekan-rekan di Fakultas Kehutanan Universitas Kuningan yang telah melakukan penelitian bersama.

\section{REFERENSI}

Alikodra (1990). Teknik Pengelolaan Satwa Liar (Dalam Rangka Mempertahankan Keanekaragaman Hayati Indonesia). IPB Press. Bogor.

Apriliano. A, Anwar. C, dan Pawhestri.SW. 2018. Keanekaragaman Jenis Burung Di Kampus UIN Raden Lintang Lampung. BIOSFER:9(2).

Bianpoen C. 1989. Fungsi Taman dalam Kota [naskah laporan]. Pusat Penelitian Teknologi dan Pemukiman Universitas Tarumanegara, Jakarta.

Booth NK, Hiss EJ. 2005. Residential Landscape Architecture: Design Process for The Private Residence. New Jersey: Pearson Prentice Hall.

Crozier.GE, Niemi.GJ.2003. Using patch and landscape variables to model bird abundance inanaturally heterogenous lands cape. Can J Zool 81:441-452.

Davidar P, Yoganand K, Garsch T. 2001. Distribution of forest bird in Andom Island importana of leg habitat.J Biogeogr 28:666-671.

Hendriani, A.S. (2016). Ruang Terbuka Hijau Sebagai Infrastruktur Hijau Kota Pada Ruang Publik Kota (Studi Kasus: AlunAlun Wonosobo). PPKM II:74-81.

Hernowo JB, Prasetyo LB. 1989. Konsepsi Ruang Terbuka Hijau di Kota sebagai Pendukung Pelestarian Burung. Media Konservasi II (4): 61-71.

Hidayat, I. 2008. Evaluasi Jalur Hijau Jalan Sebagai Penyangga Lingkungan Sekitarnya dan Keselamatan Pengguna Jalan Bebas Hambatan Jagorawi 
[Thesis]. Bogor: Sekolah Pascasarjana, Institut Pertanian Bogor.

Ludwig JA, Reynolds JF. 1988. Statistical Ecology. New York: John Wiley \& Sons.

Magurran AE. 1988. Ecological Diversity and Its Measurement. Cambridge: University Press.

Nurmaeti.C, Abidin.Z, Prianto.A. 2018. Kenakeragaman Jenis Burung Pada Zona Penyangga Taman Nasional Gunung Ciremai. Quangga:10(2)52-57.

Paramita, E. C., Kuntjoro, S., \& Ambarwati, R. (2015). Keanekaragaman dan Kelimpahan Jenis Burung di Kawasan Mangrove Center Tuban. Lenterabio, 4(3), 161-167.

Peraturan Menteri Pekerjaan Umum Nomor: 05/PRT/M/2008, tentang Pedoman Penyediaan dan Pemanfaatan Ruang Terbuka Hijau Di Kawasan Perkotaan Pendukung Pelestarian Burung. Media Konservasi II (4): 61-71.

Rohiyan M, Setyawan A, Rustiati EL. 2014. Keanekaragaman jenis burung di hutan pinus dan hutan campuran Muarasipongi Kabupaten Mandailing Natal Sumatera Utara. Jurnal Sylva Lestari 2 (2): 89-98.

Tews J, Brose U, Grimm V, Tielborger K, Wichmann MC,Schwager M, Jeltsch F (2004) Animal species diversitydriven by habitat heterogeneity/diversity: the impor-tance of keystone structures. J Biogeogr 31: 79-92. 
Tabel 3. Daftar Jenis Burung di Kampus I UNIKU

\begin{tabular}{|c|c|c|c|c|c|c|}
\hline No & Nama Daerah & Nama Ilmiah & Jumlah & DMg & $\mathbf{H}^{\prime}$ & Jenis Pakan \\
\hline 1 & Blekok sawah & Ardeola speciosa & 1 & 2,47 & 0,00 & serangga, ikan, udang \& kepiting \\
\hline 2 & Bondol haji & Lonchura maja & 9 & & 0,03 & biji-bijian \\
\hline 3 & Bondol jawa & Lonchura leucogastroides & 385 & & 0,35 & biji-bijian \\
\hline 4 & Bondol peking & BLonchura punctulata & 34 & & 0,09 & biji-bijian \\
\hline 5 & Burung-madu sriganti & Cinnyris jugularis & 15 & & 0,05 & nektar \\
\hline 6 & Cabai jawa & Dicaeum trochileum & 20 & & 0,06 & buah dan serangga \\
\hline 7 & Caladi tilik & Picoides moluccensis & 2 & & 0,01 & serangga \\
\hline 8 & Cekakak sungai & Todiramphus Chloris & 4 & & 0,02 & serangga, ikan, udang \& kepiting \\
\hline 9 & Cinenen kelabu & Orthotomus ruficeps & 1 & & 0,00 & serangga \\
\hline 10 & Gereja erasia & Passer montanus & 652 & & 0,36 & biji-bijian \\
\hline 11 & Kapinis rumah & Apus nipalensis & 2 & & 0,01 & serangga \\
\hline 12 & Kutilang & Pycnonotus aurigaster & 65 & & 0,14 & buah dan serangga \\
\hline 13 & Layang-layang loreng & Cecropis striolata & 108 & & 0,19 & serangga \\
\hline 14 & Perkutut jawa & Geopelia striata & 7 & & 0,03 & biji-bijian \\
\hline 15 & Sepah kecil & Pericrocotus cinnamomeus & 3 & & 0,01 & buah-buahan \\
\hline 16 & Tekukur biasa & Spilopelia chinensis & 41 & & 0,10 & biji-bijian \\
\hline 17 & Walet linci & Collocalia linchi & 134 & & 0,22 & serangga \\
\hline 18 & Serak Jawa & Tyto alba & 1 & & 0,00 & tikus, kadal, bahkan ula \\
\hline \multirow[t]{2}{*}{19} & Takur ungkut-ungkut & Megalaima haemacephala & 1 & & 0,00 & buah-buahan \\
\hline & Jumlah & & 1485 & & 1,67 & \\
\hline
\end{tabular}

Tabel 4. Daftar Jenis Pohon di Kampus I UNIKU

\begin{tabular}{rllrrr}
\hline No & \multicolumn{1}{c}{ Nama Lokal } & \multicolumn{1}{c}{ Nama Ilmiah } & $\begin{array}{r}\text { Jumlah } \\
\text { Individu }\end{array}$ & DMg & H' \\
\hline 1 & Akasia & Acacia mangium & 2 & 6,9 & 0,0 \\
2 & Angsana & Pterocarpus indikus & 37 & 0,2 \\
3 & Asam Kranji & Dialum indum & 1 & 0,0 \\
4 & Belimbing & Averrhoa carambola & 1 & 0,0 \\
5 & Beringin & Fikus benjamina & 1 & 0,0 \\
6 & Bintaro & Cerbera manghas & 1 & 0,0 \\
7 & Bunga Kupu Kupu & Bauhinia purpurea & 1 & 0,0 \\
8 & Bungur & Lagerstroemia & 2 & 0,0 \\
9 & Cemara & Casuarinaceae & 11 & 0,1 \\
10 & Flamboyan & Delonix regia & 10 & 0,1 \\
11 & Glodokan & Polyalthia longifolia & 86 & 0,3 \\
12 & Jabon & Neolamarckia cadamba & 10 & 0,1 \\
13 & Jati & Tectona grandis & 30 & 0,2 \\
14 & Jati Putih & Gmelina arborea & 42 & 0,2 \\
15 & Jati Solomon & Tectona grandis Linn & 1 & 0,0 \\
16 & Jengkol & Archidendron paunciflorum & 1 & 0,0 \\
17 & Kapuk & Ceiba pentandra & 11 & 0,1 \\
18 & Karet Kebo & Ficus elastica & 2 & 0,0 \\
19 & Kayu Manis & Cinnamomum verum & 1 & 0,0 \\
20 & Kelor & Moringa oleifera & 3 & 0,0
\end{tabular}




\begin{tabular}{lllrl}
21 & Kemiri & Aleurites moluccanus & 1 & 0,0 \\
22 & Kenari & Canarium ovatum & 10 & 0,1 \\
23 & Kersem & Muntingia calabura & 2 & 0,0 \\
24 & Ketapang & Terminalia catappa & 8 & 0,1 \\
25 & Ki Teja & Daphiniphylum glaucescens & 1 & 0,0 \\
26 & Kiara Payung & Filicium decipiens & 16 & 0,1 \\
27 & Lengkeng & Dimocarpus longan & 2 & 0,0 \\
28 & Mahoni & Swietenia mahagoni & 3 & 0,0 \\
29 & Mangga & Mangifera indica & 19 & 0,2 \\
30 & Matoa & Pometia pinnata & 3 & 0,0 \\
31 & Mindi & Melia azedarach & 2 & 0,0 \\
32 & Nyamplung & Calophyllum inophyllum & 8 & 0,1 \\
33 & Petai & Parkia speciosa & 1 & 0,0 \\
34 & Petai Selong & Leucaena leucocephala & 4 & 0,0 \\
35 & Rasamala & Altingia excelsa noronha & 1 & 0,0 \\
36 & Saga/celik & Abrus precatorius & 1 & 0,0 \\
37 & Salam & Syzygium polyanthum & 2 & 0,0 \\
38 & Sapu Tangan & Maniltoa grandiflora & 1 & 0,0 \\
39 & Sawo & Manikara zapota & 1 & 0,0 \\
40 & Sengon & Albizia chinensis & 15 & 0,1 \\
41 & Trembesi & Albizia saman & 12 & 0,1 \\
42 & Weni/Buni & Antidesma bunius & 11 & 0,1 \\
\hline & Jumlah Total & & $\mathbf{3 7 8}$ & $\mathbf{2 , 9}$ \\
\hline
\end{tabular}

Tabel 5. Fungsi Ekologis Pohon di Setiap Areal Penelitian Kampus I UNIKU

\begin{tabular}{|c|c|c|c|c|c|c|}
\hline Areal & Nama Lokal & Nama Ilmiah & $\begin{array}{l}\text { Jumlah } \\
\text { Individu }\end{array}$ & $\begin{array}{l}\text { Fungsi } \\
\text { Penaung }\end{array}$ & $\begin{array}{c}\text { Fungsi } \\
\text { Kontrol } \\
\text { Kelembaban }\end{array}$ & $\begin{array}{c}\text { Fungsi } \\
\text { mengundang } \\
\text { burung }\end{array}$ \\
\hline FE-FHUM & Mangga & Mangifera indica & 5 & SB & SB & SB \\
\hline \multirow[t]{7}{*}{ FKIP } & Akasia & Acacia & 1 & SB & BA & BA \\
\hline & Cemara & Casuarinaceae & 7 & BA & BA & BA \\
\hline & Glodokan & Polyalthia longifolia & 3 & BA & KB & BA \\
\hline & Jengkol & Archidendron paunciflorum & 1 & BA & BA & BA \\
\hline & Kenari & Canarium ovatum & 5 & SB & SB & SB \\
\hline & Ketapang & Terminalia catappa & 1 & SB & SB & SB \\
\hline & Krey Payung & Filicium decipiens & 3 & SB & SB & SB \\
\hline \multirow[t]{5}{*}{ MDM } & Glodokan & Polyalthia longifolia & 1 & BA & KB & KB \\
\hline & Krey Payung & Casuarinaceae & 7 & SB & SB & SB \\
\hline & Mangga & Polyalthia longifolia & 3 & SB & SB & SB \\
\hline & Pucuk Merah & Archidendron paunciflorum & 1 & KB & KB & KB \\
\hline & Sawo & Canarium ovatum & 5 & SB & SB & SB \\
\hline \multirow[t]{11}{*}{ FHUT-KSR-SC } & Akasia & Acacia mangium & 1 & SB & BA & BA \\
\hline & Angsana & Pterocarpus indikus & 1 & SB & SB & SB \\
\hline & Bintaro & Cerbera manghas & 1 & BA & KB & $\mathrm{KB}$ \\
\hline & Bunga Kupu Kupu & Bauhinia purpurea & 1 & SB & BA & BA \\
\hline & Bungur & Lagerstroemia & 1 & SB & SB & SB \\
\hline & Flamboyan & Delonix regia & 2 & SB & SB & SB \\
\hline & Glodokan & Polyalthia longifolia & 2 & BA & KB & SB \\
\hline & Jabon & Neolamarckia cadamba & 10 & BA & BA & BA \\
\hline & Jati & Tectona grandis & 22 & BA & BA & BA \\
\hline & Jati Putih & Gemelina arborea & 33 & SB & BA & BA \\
\hline & Kapuk & Ceiba pentandra & 2 & $\mathrm{SC}$ & BA & BA \\
\hline
\end{tabular}


Quagga: Jurnal Pendidikan dan Biologi

Volume 12, Nomor 2, Juli 2020, pp.145-155
p-ISSN 1907-3089, e-ISSN2651-5869

https://journal.uniku.ac.id/index.php/quagga

\begin{tabular}{|c|c|c|c|c|c|c|}
\hline & Kelor & Moringa oleifera & 1 & $\mathrm{~KB}$ & BU & $\mathrm{BU}$ \\
\hline & Kemiri & Aleurites moluccanus & 1 & SB & SB & SB \\
\hline & Kenari & Canarium ovatum & 4 & SB & SB & SB \\
\hline & Kersem & Muntingia calabura & 2 & SB & SB & SB \\
\hline & Ketapang & Terminalia catappa & 5 & SB & SB & SB \\
\hline & Ki Teja & Daphiniphylum glaucescens & 1 & SB & BA & $\mathrm{BA}$ \\
\hline & Krey Payung & Filicium decipiens & 7 & SB & SB & SB \\
\hline & Lengkeng & Dimocarpus longan & 2 & SB & SB & $\mathrm{BA}$ \\
\hline & Mahoni & Swietenia mahagoni & 1 & SB & SB & SB \\
\hline & Mangga & Mangifera indica & 3 & SB & SB & SB \\
\hline & Mindi & Melia azedarach & 1 & KB & KB & $\mathrm{KB}$ \\
\hline & Nyamplung & Calophyllum inophyllum & 1 & KB & KB & $\mathrm{KB}$ \\
\hline & Petai & Parkia speciosa & 1 & BA & $\mathrm{KB}$ & KB \\
\hline & Petai Selong & Leucaena leucocephala & 3 & BA & $\mathrm{KB}$ & $\mathrm{KB}$ \\
\hline & Saga/celik & Saga/celik & 1 & BA & $\mathrm{KB}$ & $\mathrm{KB}$ \\
\hline & Sapu Tangan & Sapu Tangan & 1 & BA & $\mathrm{KB}$ & KB \\
\hline & Sawo & Sawo & 3 & SB & SB & SB \\
\hline & Sengon & Albizia chinensis & 12 & BA & KB & KB \\
\hline & Trembesi & Albizia saman & 4 & SB & SB & SB \\
\hline \multirow[t]{15}{*}{ PMM } & Angsana & Pterakarpuse indica & 4 & SB & SB & SB \\
\hline & Bungur & Lagerstroemia & 1 & SB & SB & SB \\
\hline & Jati & Tectona grandis & 8 & BA & BA & $\mathrm{BA}$ \\
\hline & Jati Putih & Gemelina arborea & 9 & SB & BA & $\mathrm{BA}$ \\
\hline & Kapuk & Ceiba pentandra & 6 & BA & BA & $\mathrm{BA}$ \\
\hline & Kayu Manis & Cinnamomum verum & 1 & SB & BA & $\mathrm{BA}$ \\
\hline & Kelor & Moringa oleifera & 2 & KB & BU & $\mathrm{KB}$ \\
\hline & Ketapang & Terminalia cattapa & 2 & SB & SB & SB \\
\hline & Mahoni & Swietenia mahagoni & 4 & SB & SB & SB \\
\hline & Matoa & Pometia pinnata & 3 & BA & $\mathrm{KB}$ & KB \\
\hline & Nyamplung & Calophyllum inophyllum & 3 & $\mathrm{~KB}$ & $\mathrm{~KB}$ & KB \\
\hline & Petai Selong & Leucaena leucocephala & 1 & BA & $\mathrm{KB}$ & KB \\
\hline & Rasamala & Altingia excelsa noronha & 1 & BA & KB & $\mathrm{KB}$ \\
\hline & Salam & Syzygium polyanthum & 1 & SB & BA & $\mathrm{BA}$ \\
\hline & Trembesi & Albizia saman & 5 & SB & SB & SB \\
\hline \multirow[t]{10}{*}{ Rektorat } & Angsana & Pterocarpus indikus & 2 & SB & SB & SB \\
\hline & Belimbing & Averrhoa carambola & 1 & KB & KB & $\mathrm{KB}$ \\
\hline & Cemara & Casuarinaceae & 4 & BA & BA & $\mathrm{BA}$ \\
\hline & Glodokan & Polyalthia longifolia & 30 & BA & KB & $\mathrm{KB}$ \\
\hline & Krey Payung & Filicium decipiens & 3 & SB & SB & SB \\
\hline & Mahoni & Swietenia mahagoni & 1 & SB & SB & SB \\
\hline & Mangga & Mangifera indica & 2 & $\mathrm{~S}$ & SB & SB \\
\hline & Nyamplung & Calophyllum inophyllum & 2 & $\mathrm{~KB}$ & $\mathrm{~KB}$ & KB \\
\hline & Trembesi & Albizia saman & 2 & SB & SB & SB \\
\hline & Weni/Buni & Antidesma bunius & 1 & BA & $\mathrm{KB}$ & $\mathrm{KB}$ \\
\hline \multirow[t]{7}{*}{ Fkom } & Angsana & Pterocarpus indikus & 2 & SB & SB & SB \\
\hline & Belimbing & Averrhoa carambola & 1 & KB & KB & KB \\
\hline & Cemara & Casuarinaceae & 4 & BA & BA & $\mathrm{BA}$ \\
\hline & Glodokan & Polyalthia longifolia & 30 & KB & KB & $\mathrm{KB}$ \\
\hline & Krey Payung & Filicium decipiens & 3 & SB & SB & SB \\
\hline & Mahoni & Swietenia mahagoni & 1 & SB & SB & SB \\
\hline & Mangga & Mangifera indica & 2 & SB & SB & SB \\
\hline \multirow[t]{5}{*}{ Lap. Upc-SGT } & Angsana & Pterocarpus indikus & 28 & SB & SB & SB \\
\hline & Beringin & Fikus benjamina & 1 & SB & SB & SB \\
\hline & Flamboyan & Delonix regia & 4 & SB & SB & SB \\
\hline & Glodokan & Polyalthia longifolia & 15 & $\mathrm{~KB}$ & $\mathrm{~KB}$ & $\mathrm{~KB}$ \\
\hline & Jati Solomon & Tectona grandis Linn & 1 & $\mathrm{SB}$ & $\mathrm{BA}$ & $\mathrm{BA}$ \\
\hline
\end{tabular}


Quagga: Jurnal Pendidikan dan Biologi

Volume 12, Nomor 2, Juli 2020, pp.145-155
p-ISSN 1907-3089, e-ISSN2651-5869

https://journal.uniku.ac.id/index.php/quagga

\begin{tabular}{llllll} 
Karet Kebo & Ficus elastica & 2 & SB & SB & SB \\
Kenari & Canarium ovatum & 1 & SB & SB & SB \\
Mangga & Mangifera indica & 2 & SB & SB & SB \\
Nyamplung & Calophyllum inophyllum & 2 & KB & KB & KB \\
Sawo & Manikara zapota & 9 & SB & SB & SB \\
\hline
\end{tabular}

Keterangan:

SB = Sangat Baik

$\mathrm{BA}=$ Baik

$\mathrm{KB}=$ Kurang Baik

$\mathrm{BU}=$ Buruk 